\title{
Cytotoxic Effect of Triglycerides via Apoptotic Caspase Pathway in Immune and Non-immune Cell Lines
}

\author{
Jaewon Lim ${ }^{\S, *}$, Eun Ju Yang ${ }^{\S, *}$ and Jeong Hyun Chang ${ }^{\dagger, *}$ \\ Department of Clinical Laboratory Science, College of Medical Sciences, \\ Daegu Haany University, Gyeongsan 38610, Korea
}

\begin{abstract}
Hyperlipidemia is defined as conditions of the accumulation of lipids such as free fatty acids (FFA), triglyceride (TG), cholesterol and/or phospholipid in the bloodstream. Hyperlipidemia can cause lipid accumulation in non-adipose tissue, which is lipid-cytotoxic effects in many tissues and mediates cell dysfunction, inflammation or programmed cell death (PCD). TG is considered to be a major cause of atherosclerosis through inflammatory necrosis of vascular endothelial cells. Recently, TG have also been shown to exhibit lipid-cytotoxicity and induce PCD. Therefore, we investigated the effect of TG on the cytotoxic effect of various cell types. When exposed to TG, the cell viability of U937 monocytes and Jurkat $\mathrm{T}$ lymphocytes, as well as the cell viability of MCF-7, a non-immune cell, decreased in time- and dose-dependent manner. In U937 cells and Jurkat cells, caspase-9, an intrinsic apoptotic caspase, and caspase-8, an extrinsic apoptotic caspase, were increased by exposure to TG. However, in TG-treated MCF-7 cells, caspase- 8 activity increased only without caspase- 9 activity. In addition, the reduction of cell viability by TG was recovered when all three cell lines were treated with pan-caspase inhibitor. These results suggest that activation of apoptotic caspases by TG causes lipotoxic effect and decreases cell viability.
\end{abstract}

Key Words: Triglyceride (TG), Lipotoxic effect, Apoptotic caspase, Caspase-8, Caspase-9

\section{서 론}

고지혈증(hyperlipidemia)은 지속적인 과영양상태(overnutrition), 또는 유전적 결함(genetic defect) 등에 의해서 혈 액 내에서 유리 지방산(free fatty acid, FFA), 중성지방(triglyceride, TG), 콜레스테롤(cholesterol) 또는 인지질(phospholipid) 같은 지질(lipid)의 농도가 증가된 상태를 의미한다 (Frayn, 2002; Kusminski et al., 2009; Johnson et al., 2013; Menet et al., 2018). 고지혈증은 혈액 내 증가된 지질의 농도에 의 해 비 지방 조직(non-adipose tissue)에서 비정상적인 지질
의 축적을 일으키게 되고 이때 세포의 기능 장애나 세포 사멸 등을 일으키게 되고 이러한 현상을 지방독성 효과 (lipotoxic effect)라 한다(Aronis et al., 2008). 이러한 지방 축 적에 의한 세포독성 효과는 간세포(hepatocyte), 심근세포 (cardiomyocyte) 및 대식세포(macrophage) 등 다양한 세포 에서 나타나는 것으로 보고가 되고 있다(de Vries et al., 1997; Aronis et al., 2005; Malhi et al., 2006). 그리고 지방 축 적에 의한 세포의 기능 이상이나 세포사멸은 고지혈증에 의해 유발되는 다양한 염증성 질환의 원인 중 하나로 알 려져 있으며, 그 중 대표적인 예가 급성 심근경색(acute myocardiac infarction)이나 허혈성 심질환(ischemic heart dis-

Received: January 28, 2019 / Revised: February 25, 2019 / Accepted: March 12, 2019

*Professor.

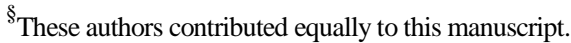

'Corresponding author: Jeong-Hyun Chang. Department of Clinical Laboratory Science, College of Medical Science, Daegu Haany University, Gyeongsan 38610, Korea.

Tel: +82-53-819-1350, Fax: +82-53-819-1353, e-mail: jhchang@dhu.ac.kr

(C) The Korean Society for Biomedical Laboratory Sciences. All rights reserved.

(c) This is an Open Access article distributed under the terms of the Creative Commons Attribution Non-Commercial License (http://creativecommons.org/licenses/by-nc/3.0/) which permits unrestricted non-commercial use, distribution, and reproduction in any medium, provided the original work is properly cited. 
ease) 등의 원인이 되는 죽상동맥경화증(atherosclerosis)이 다(Carmena et al., 2004).

중성지방은 콜레스테롤이나 유리 지방산과 더불어 지방 독성 효과를 나타내는 주요한 인자 중 하나로 알려져 있 다(Cury-Boaventura et al., 2006). 이전의 여러 연구에서 죽 상동맥경화증에 관여하는 면역계 세포(immune cells) 중 하나인 대식세포의 경우, 고지혈증 환자의 혈중 중성지방 농도와 유사한 고농도의 중성지방에 노출 시 미토콘드리 아(mitochondria)의 기능 이상 및 활성산소종(reactive oxygen species, ROS) 증가로 인한 산화적 스트레스(oxidative stress) 에 의해 세포사멸유도(programmed cell death, PCD)가 일어 난다고 보고하고 있다(Aronis et al., 2005; Aronis et al., 2008; Aflaki et al., 2011; Son et al., 2013; Lim et al., 2017). 그리고 중성지방에 의한 대식세포의 세포사멸유도는 죽상동맥경 화증 발달에 기여하며 병을 일으키는 원인 중 하나로 여 겨지고 있다(Hokanson and Austin, 1996; Malloy and Kane, 2001; Toth, 2016; Kamstrup, 2017). 결과적으로 중성지방에 의한 세포사멸유도는 고지혈증에 의해 발생 가능한 염증 성 질환의 발달 과정에 중요 인자 중 하나라 할 수 있으 며 고지혈증 환자에게 발생 가능한 질환의 기전 연구에 있어 매우 중요한 부분이다. 따라서 본 연구에서는 대식 세포 외에도 다양한 염증성 질환에 관여하는 면역계 세포 중 하나인 U937 단핵구 세포주와 Jurkat T 림프구 세포주, 그리고 대조군으로 유방암 상피세포주인 MCF-7을 이용 하여 중성지방에 노출 시 면역계 세포 및 비-면역계 세포 (non-immune cell)에서 세포사멸유도에 의한 세포 수 감소 가 나타나는지 확인하였다.

세포사멸유도와 관련된 대표적인 경로 중 하나인 apoptotic caspase 기전(apoptotic caspase pathway)은 caspase라 불 리는 cysteine proteases 단백질 군집의 복합적인 활성화 반 응에 의해 일어나고 그 결과, 세포질의 응축 및 DNA 절 단 및 절편형성을 초래하면서 세포사멸을 유도하게 된다 (Norbury and Hickson, 2001; Elmore, 2007). 그리고 이 반응 에서 $\mathrm{DNA}$ 의 손상을 방지하는 단백질 중 하나인 poly $\mathrm{ADP}$ ribose polymerase (PARP)는 apoptotic caspase의 활성화에 의 해 cleaved form을 형성하며 불활성화되면서 세포사멸유도 에 관여하게 되고 이것은 이 반응의 중요 기전이면서 동 시에 caspase 활성화에 의한 세포사멸의 중요한 검증 지표 (hallmark)이다(Deveraux and Reed, 1999). Apoptotic caspase 기전에는 크게 2종류의 경로가 존재한다. 첫 번째 경로는 세포 밖 수용체에 의한 자극에 의해 유발되는 extrinsic 경 로로 caspase 단백질 중 주로 caspase-8가 관여하는 것으
로 알려져 있다. Death domain (DD)라 불리는 세포질 내 domain은 외부의 자극을 세포 내 신호전달 경로로 전달 하며 caspase-8을 활성화하게 되고 이것에 의해 세포사멸 반응이 유도된다(Kischkel et al., 1995; Elmore, 2007). 두 번 째 경로는 intrinsic 경로라 하는데 그 이유는 세포 밖 신호 전달을 매개하는 수용체 자극이 아닌 내부 자극에 의해 유도되기 때문이다. 주요 경로는 미토콘드리아의 기능 이 상으로 인해 미토콘드리아 내 cytochrome c가 세포질 내로 방출되고 이것에 의해 caspase-9이 활성화되면서 intrinsic 경로가 시작하게 된다(Cory and Adams, 2002; Saelens et al., 2004). 본 연구에서는 중성지방에 의한 세포의 생존율 감 소에 apoptotic caspase 기전의 관련 여부를 확인하였다. 그 리고 그 기전이 실제 세포의 생존율과 관련성이 있는지 특이적 억제제를 이용하여 관련 기전을 규명하였다.

본 연구에서는 중성지방에 의한 세포사멸유도 과정을 규명함에 있어 면역계 세포인 U937 및 Jurkat 세포주와 비-면역계 세포인 MCF-7 세포주를 이용해 중성지방 처리 후 세포의 생존율이 어떻게 변화화는 지 확인하였고 실험 을 진행하였다. 그리고 이를 통해 면역계 세포 및 비-면 역계 세포에서 모두 중성지방에 의한 지방독성 효과에 의 한 세포 생존율이 감소하는 것을 확인하였다. 그리고 중 성지방에 의한 세포사멸이 apoptotic caspase를 경유하여 나타나는 것을 볼 수 있었다.

\section{재료 및 방법}

\section{재료}

중성지방 유탁액(TG emulsion, Lipofundin ${ }^{\circledR} \mathrm{MCT} / \mathrm{LCT}$ 20\%)은 B. Braun Melsungen AG (Melsungen, Germany)에서 구매하였다. 이전에 여러 연구에서 세포에 중성지방 노출 시 Lipofundin ${ }^{\circledR}$ MCT/LCT $20 \%$ 을 사용하였다. Lipofundin ${ }^{\circledR}$ $\mathrm{MCT} / \mathrm{LCT} 20 \%$ 의 조성은 다음과 같다; $100 \mathrm{~g} / \mathrm{L}$ medium chain triglyceride, soybean oil, glycerol, egg lecithin, all-rac$\alpha$-tocopherol 및 sodium oleate. 본 연구에서는 Lipofundin ${ }^{\circledR}$ $\mathrm{MCT} / \mathrm{LCT} 20 \%$ 을 이용하여 세포에 중성지방을 노출시켰 으며, 따라서 중성지방으로 혼용표기 하였다(Aronis et al., 2005). Pan-caspase 억제제인 z-VAD-FMK는 Sigma-Aldrich (St. Louis, MO, USA)에서 구매하였다. Western-blot 분석 시 사용한 cleaved caspase-8, cleaved caspase-9 및 cleaved PARP 단백질에 대한 특이적인 항체는 Cell Signaling Technology (Danvers, MA, USA)에서 구매 후 사용하였다. 


\section{세포 배양}

U937 (ATCC, Manassas, VA, USA) 단핵구 및 Jurkat (ATCC) $\mathrm{T}$ 림프구 세포주는 $10 \%$ fetal bovine serum (FBS) 및 $1 \%$ penicillin-streptomycin이 첨가된 RPMI 1640 배지에서 배양하였다. MCF-7 (ATCC) 유방암 상피세포 세포주는 $10 \%$ fetal bovine serum (FBS) 및 1\% penicillin-streptomycin이 첨가된 $\mathrm{DMEM}$ 배지에서 배양하였다. 배양 조건은 습기 가 첨가된 $5 \% \mathrm{CO}_{2}$ 에서 $37^{\circ} \mathrm{C}$ 를 유지하였다. 실험 조건은 6-well plate에 $2.5 \times 10^{5}$ cells/well 농도가 되도록 세포를 심은 이후 중성지방 및 억제제를 처리한 후 24시간 또는 48시간 동안 배양하였다.

\section{세포 생존율(cell viability) 확인}

세포의 생존율을 확인하기 위해 세포가 포함된 배지 $10 \mu \mathrm{L}$ 와 Trypan blue 염색액 $10 \mu \mathrm{L}$ 를 1:1 비율로 혼합하는 초생체 염색(supravital stain)을 시행하였다. 세포 수 개수를 위해 hemocytometer를 이용하여 염색이 되지 않은 세포를 살아있는 세포라 가정하고 개수하였다.

\section{Western-blot 분석}

단백질 분석을 하기 위해 $\mathrm{PBS}$ 로 세포를 세척한 후, $4^{\circ} \mathrm{C}$ 조건 하에서 Triton X-100 (Sigma-Aldrich) 및 protease inhibitor cocktail (Sigma-Aldrich)이 포함된 세포 용해액(cell lysis buffer)을 이용해 세포를 용해시킨 뒤 단백질 상층액 을 얻어 실험에 이용하였다. Western-blot 분석은 이전에 기술된 바와 같이 진행하였다(Lim et al., 2014).

\section{통계 분석}

통계 분석에는 GraphPad Prism 5 (GraphPad Software Inc., San Diego, CA, USA)를 사용하였다. $P$-value 값은 Student's $t$-test를 사용하여 계산하였다. 모든 값은 평균(mean) 및 평 균의 표준 오차(standard error of the mean, SEM)로 표시하 였다. 각 실험은 3 회 씩 실행하였고 각 실험 결과를 토대 로 통계적 분석을 실시하였다. 통계적으로 유의 하다고 판단되는 결과에 대해선 다음과 같이 표기하였다; $* P<$ $0.05, * * P<0.01$ 및 $* * * P<0.001$.

\section{결 과}

중성지방에 의한 시간 의존적, 농도 의존적인 세포 수 감소

Aronis 등의 연구에 따르면 중성지방이나 지방산 등은
지방독성 효과를 나타내며 각각 독립적인 경로에 의해 대 식세포와 같은 면역계 세포의 생존율 감소를 유발한다 (Aronis et al., 2008). 따라서 본 연구에서는 면역계 세포주 중 단핵구 세포주인 U937 세포주, T 림프구 세포주인 Jurkat 세포주를 이용하여 중성지방에 의한 면역계 세포의 생존율 변화를 관찰하기 위한 실험을 진행하였다. 그리고 그 대조군으로 비-면역계 세포주인 MCF-7 세포주를 사 용하였다. 실험한 결과, 단핵구 세포주인 U937의 경우 저 농도의 중성지방 $(0.1 \mathrm{mg} / \mathrm{mL})$ 에 24시간만 노출되더라도 세포 생존율이 감소가 뚜렷하게 나타났고, 같은 농도로 48 시간 노출되었을 때 그 수가 절반 이하로 감소하는 것 을 확인할 수 있었다(Fig. 1A and 1B). 반면 $\mathrm{T}$ 림프구 세포 주인 Jurkat의 경우 중성지방에 24시간 노출 시에는 $0.5 \mathrm{mg}$ $/ \mathrm{mL}$ 에서 세포 생존율 감소가 뚜렷하게 나타나기 시작하 였고, 38시간 노출 시에도 U937 세포에 비해 중성지방에 대한 감수성이 낮게 나타나는 것을 보여주었다(Fig. 1C and 1D). 또한, 대조군인 비-면역계 세포주인 MCF-7의 경 우 예상과 다르게 중성지방의 처리 시간 및 농도에 대해 다른 면역계 세포주와 유사하게 지방독성 효과를 나타내 며 세포 생존율이 감소하는 것을 확인하였다(Fig. $1 \mathrm{E}$ and $1 \mathrm{~F})$. 본 실험 결과에서 면역계 세포주의 경우 세포의 종류 에 따라 중성지방에 의한 지방독성 효과에 대한 감수성은 다르게 나타나는 것을 확인하였다. 또한, 비-면역계 세포 주에서도 중성지방에 대한 지방독성 효과가 나타나는 것 을 확인할 수 있었다.

\section{중성지방에 의한 apoptotic caspase 경로의 활성 증가 와 cleaved PARP의 증가}

중성지방의 세포 내 축적은 대식세포의 세포사멸을 초 래하고, 세포사멸 경로 중 하나로 apoptotic caspase 경로 가 알려져 있다(Aflaki et al., 2011; Lim et al., 2017). 앞선 결과에서 중성지방에 의한 세포 생존율 감소에 apoptotic caspase 중 intrinsic pathway와 관련한 caspase-9과 extrinsic pathway와 관련한 caspase-8이 관여하는지 확인하기 위 해 Western-blot 기법을 이용하여 확인하였다. 그 결과, U937 세포주와 Jurkat 세포주에서 모두 중성지방 처리 시 caspase-8과 caspase-9의 활성화에 의해 cleaved-form이 증 가하는 것을 확인하였다(Fig. $2 \mathrm{~A}$ and $2 \mathrm{~B}$ ). 반면, MCF-7 세 포주의 경우 중성지방 처리 시 caspase-8의 활성도만 증 가하는 것을 확인하였다. Caspase-9의 cleaved-form의 경 우 Western-blot 상에서 나타나지 않았다(Fig. 2C). 세포 내 apoptotic caspase 기전 활성 시 불활성화 되어 apoptosis에 
A

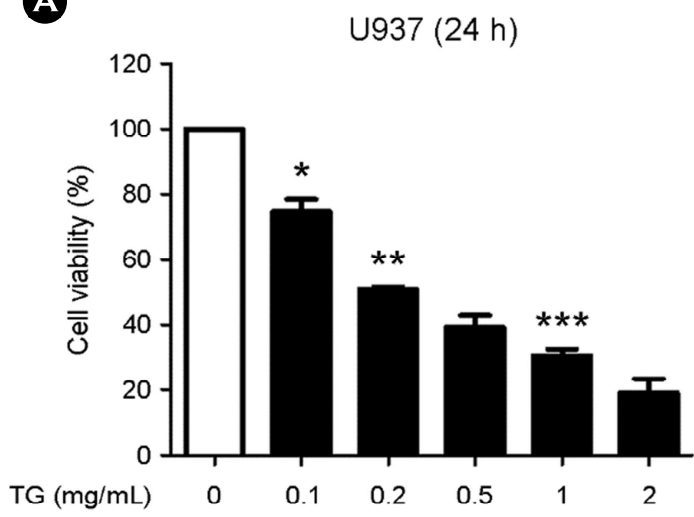

C

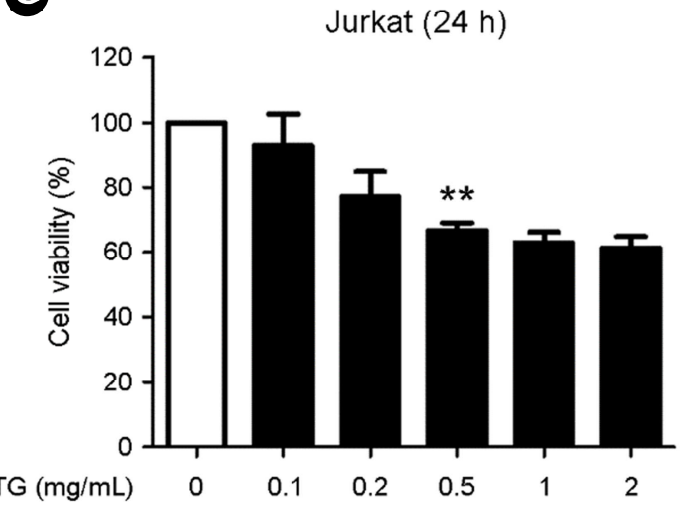

E

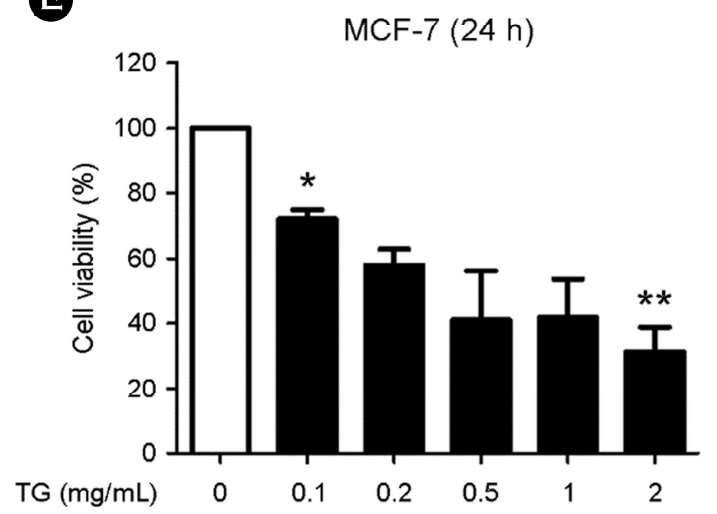

B

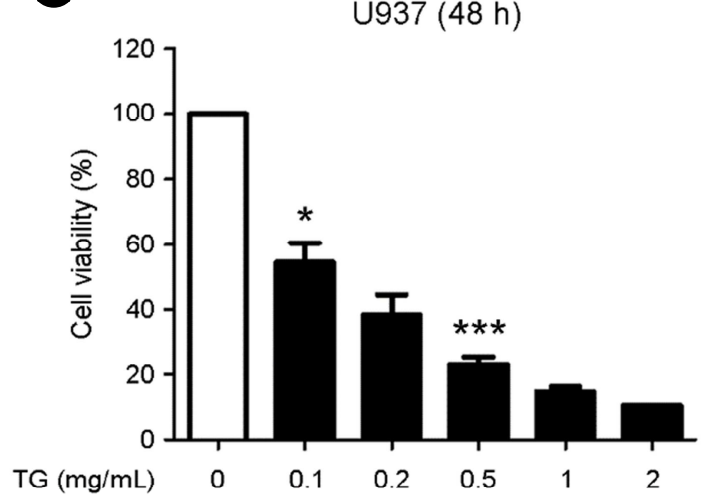

D

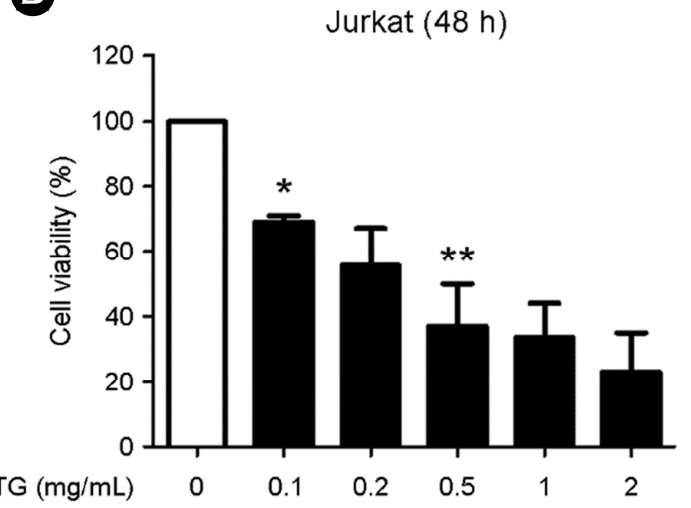

F

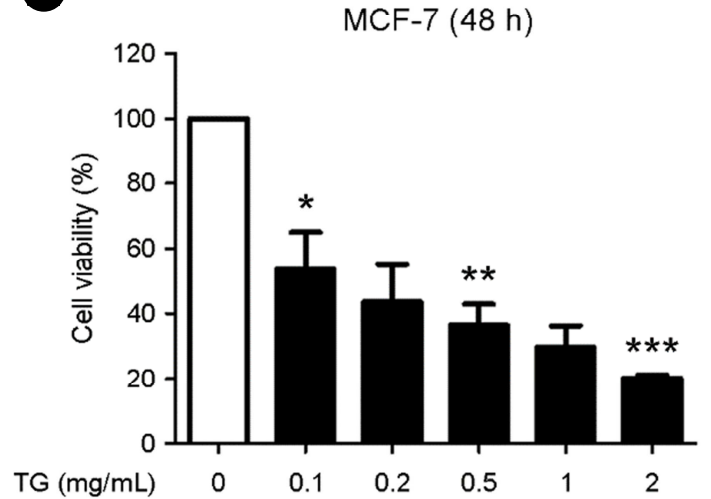

Fig. 1. TG reduces cell viability in a time- and dose-dependent manner. (A) and (B) U937 monocytes were incubated with TG ( 0 , 0.1 , $0.2,0.5,1$, and $2 \mathrm{mg} / \mathrm{mL}$ ) for indicates times ( 24 and $48 \mathrm{~h})$. (C) and (D) Jurkat T lymphocytes were incubated with TG $(0,0.1,0.2,0.5,1$, and $2 \mathrm{mg} / \mathrm{mL})$ for indicates times (24 and $48 \mathrm{~h})$. (E) and (F) MCF-7 epithelial cells were incubated with TG (0, 0.1, 0.2, 0.5, 1, and $2 \mathrm{mg} / \mathrm{mL})$ for indicates times $(24$ and $48 \mathrm{~h}$ ). The trypan blue exclusion assay was performed to detect the cell viability of cell lines. The cell viability $(\%)$ of cells without TG treatment was set as 100 . Data are expressed as the mean \pm SEM from three independent experiments. $P$-values were determined by the Student's $t$-test. $* P<0.05$, ** $P<0.01$ and $* * * P<0.001$.

기여하는 PARP 단백질의 변화를 확인한 결과, 모든 세 포주에서 cleaved form의 증가로 인해 불활성화 되는 것
을 확인하였다(Fig. 2A, 2B and 2C). 본 실험 결과를 바탕 으로 면역계 세포주와 비-면역계 세포주 모두 중성지방 
A

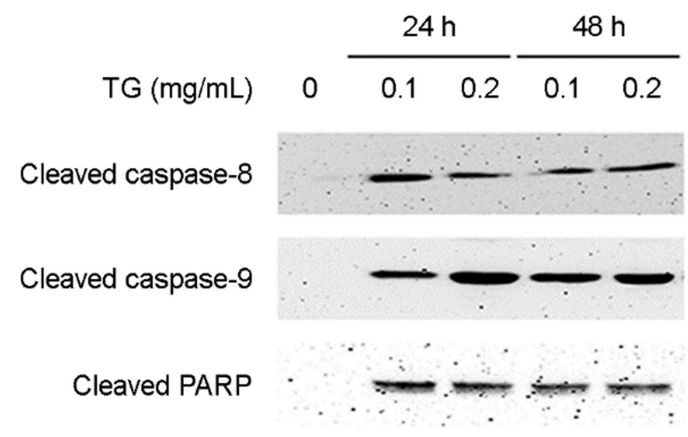

B

Jurkat

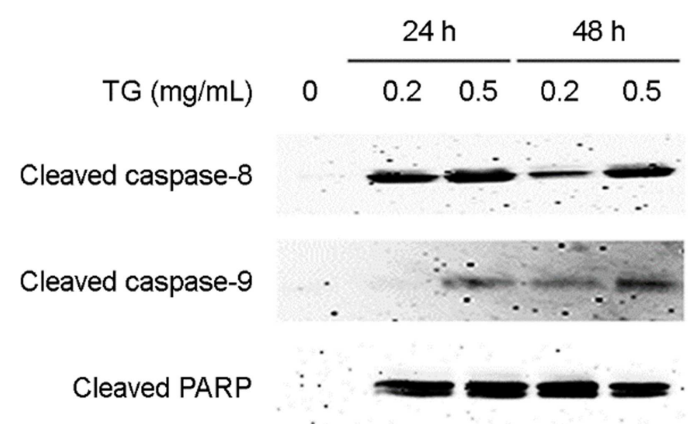

C

MCF-7

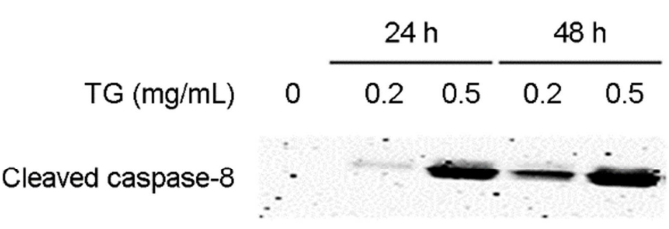

Cleaved caspase- 9

Cleaved PARP

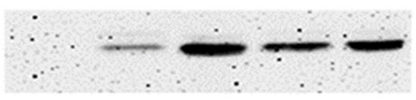

Fig. 2. TG induced the activation of apoptotic caspase pathway. (A) U937 monocytes were incubated with TG $(0,0.1$ and $0.2 \mathrm{mg} /$ $\mathrm{mL}$ ) for indicates times (24 and $48 \mathrm{~h}$ ). (B) Jurkat $\mathrm{T}$ lymphocytes were incubated with TG $(0,0.2$ and $0.5 \mathrm{mg} / \mathrm{mL})$ for indicates times (24 and $48 \mathrm{~h}$ ). (C) MCF-7 epithelial cells were incubated with TG $(0,0.2$ and $0.5 \mathrm{mg} / \mathrm{mL})$ for indicates times $(24$ and $48 \mathrm{~h})$. Cleavage of caspase-8, caspase- 9 and PARP was detected by Western-blot analysis using anti-caspase- 8 antibody, anti-caspase- 9 antibody and anti-PARP antibody. A representative image is shown from three independent experiments.

에 노출 시 apoptotic caspase 기전의 활성화에 의한 PARP 단백질의 불활성화가 일어나는 것을 확인할 수 있었다. 그
러나 U937과 Jurkat 세포주는 중성지방에 노출 시, caspase8과 caspase-9의 활성이 모두 증가한 반면 MCF-7 세포주 는 caspase-8의 활성만 증가하는 것을 확인하였다.

\section{중성지방에 의해 활성화된 apoptotic caspase 기전을 통한 세포 생존율 감소}

앞선 결과에서 중성지방에 노출 시 면역계 세포 및 비 -면역계 세포 모두 세포 생존율의 감소가 나타나며, 동시 에 caspase-8 또는 caspase-9의 활성도 증가와 PARP 단백 질의 불활성화가 나타나는 것을 확인하였다. 따라서 세포 의 생존율 감소가 apoptotic caspase의 활성과 직접적으로 연관이 있는지 확인하기 위한 실험을 진행하였다. 먼저 중성지방에 의한 caspase-8 또는 caspase-9의 활성 증가와 PARP 단백질의 불활성화가 관련이 있는지 확인하기 위하 여 pan-caspase 억제제인 z-VAD-fmk를 각 세포주에 농도 별로 처리한 후 PARP 단백질의 cleaved form의 양상을 관 찰한 결과, U937 세포주 및 Jurkat 세포주에서 모두 PARP 단백질의 cleaved form이 다시 감소하면서 회복되는 것을 관찰하였다(Fig. 3A and 3B). 반면 MCF-7 세포주의 경우 면역계 세포주와 유사하게 PARP 단백질이 회복되는 것은 관찰되었으나 그 양상은 좀더 더디게 나타나는 것을 확인 하였다(Fig. 3C). 이어서 세포주 별 세포 생존율을 확인한 결과, 세 세포주 모두 caspase 활성 억제 시 중성지방에 의 해 감소한 세포 생존율이 일부 회복되는 양상을 나타냈다. 중성지방에 대한 감수성이 높은 U937의 경우에는 Z-VAD$\mathrm{fmk}$ 를 $10 \mu \mathrm{M}$ 처리 시 세포 생존율이 대조군 대비 평균 $83.9 \%$ 까지 회복이 되었으나, Jurkat 세포주는 평균 $72.3 \%$ 의 세포 생존율을 보여 $10 \%$ 정도 차이가 나타났다(Fig. 4A and 4B). 반면, 비-면역계 세포주인 MCF-7의 경우 세포 생존율은 일부 회복이 되나 그 정도는 면역계 세포주에 비해 다소 낮게 나타나는 것을 보였다(Fig. 4C). 본 결과를 바탕으로 중성지방에 의한 노출 시 나타나는 세포의 생 존율 감소 기전에는 apoptotic caspase 중 하나인 caspase-8 또는 caspase-9이 관여를 하게 된다는 것을 확인할 수 있 었다.

\section{고 찰}

본 연구에서는 중성지방이 세포에 노출 시 나타나는 지 방독성 효과에 대한 평가와 더불어 지방독성 효과에 어 떠한 기전이 관여하는지 확인하였다. 기존의 연구 결과에 서는 중성지방에 의한 세포독성 효과와 관련 기전에 대해 
A

U937 (48 h)

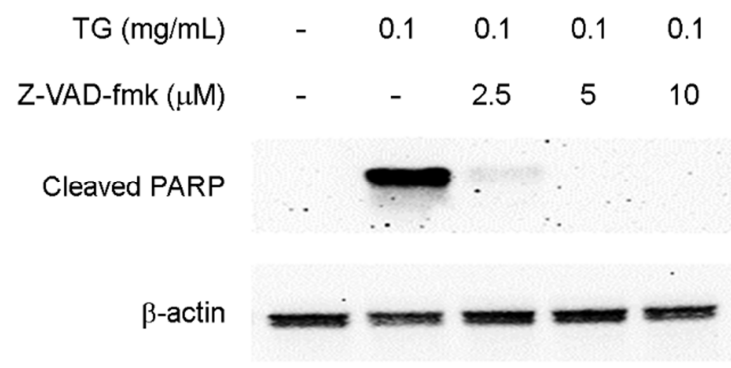

B

Jurkat (48 h)

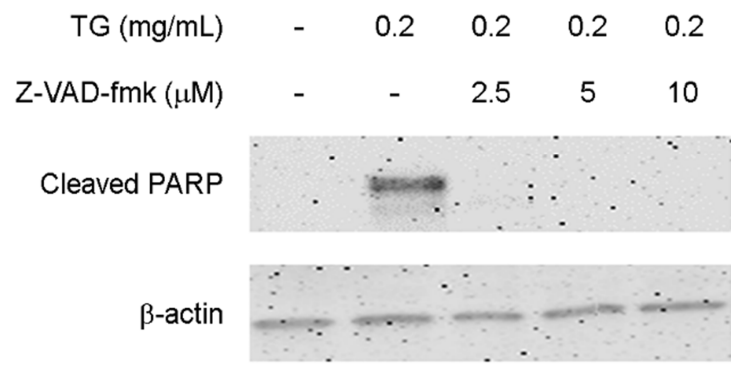

C

MCF-7 (48 h)

$\begin{array}{rccccc}\text { TG }(\mathrm{mg} / \mathrm{mL}) & - & 0.2 & 0.2 & 0.2 & 0.2 \\ \text { Z-VAD-fmk }(\mu \mathrm{M}) & - & - & 2.5 & 5 & 10 \\ \text { Cleaved PARP } & - & & & & \end{array}$

$\beta$-actin

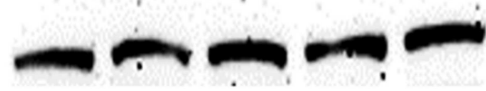

Fig. 3. TG increases the PARP-cleaved form via caspase-8 and caspase-9. (A) U937 monocytes were incubated with $0.1 \mathrm{mg} / \mathrm{mL}$ of TG in the presence of the pan-caspase inhibitor, z-VAD-FMK $(0$, $2.5,5$ and $10 \mu \mathrm{M}$ ) for $48 \mathrm{~h}$. (B) Jurkat T lymphocytes were incubated with $0.2 \mathrm{mg} / \mathrm{mL}$ of TG in the presence of the pan-caspase inhibitor, $\mathrm{z}$-VAD-FMK $(0,2.5,5$ and $10 \mu \mathrm{M})$ for $48 \mathrm{~h}$. (C) MCF-7 epithelial cells were incubated with $0.2 \mathrm{mg} / \mathrm{mL}$ of TG in the presence of the pan-caspase inhibitor, z-VAD-FMK $(0,2.5,5$ and $10 \mu \mathrm{M})$ for $48 \mathrm{~h}$. Cleavage of PARP was detected by Western-blot analysis using anti-PARP antibody. $\beta$-actin was used as an internal control. A representative image is shown from three independent experiments.

주로 염증 질환에 초점을 맞추어 대식세포, 단핵구 또는 $\mathrm{T}$ 림프구 등 면역계 세포에 대한 연구가 주를 이루었다 (Son et al., 2013; Toth, 2016). 그러나 본 연구에서는 면역계
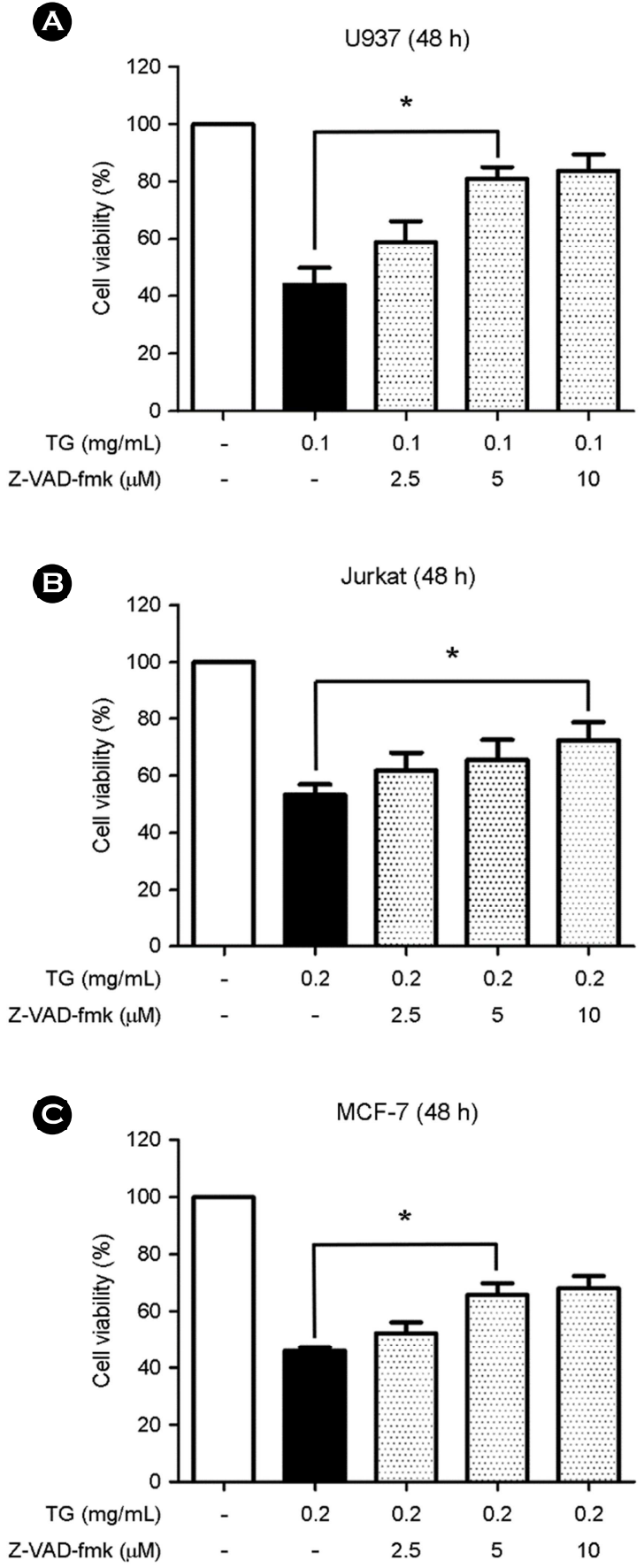

Fig. 4. TG reduces cell viability via apoptotic caspase pathway. (A) U937 monocytes were incubated with $0.1 \mathrm{mg} / \mathrm{mL}$ of TG in the presence of the pan-caspase inhibitor, z-VAD-FMK $(0,2.5,5$ and $10 \mu \mathrm{M}$ ) for $48 \mathrm{~h}$. (B) Jurkat T lymphocytes were incubated with $0.2 \mathrm{mg} / \mathrm{mL}$ of TG in the presence of the pan-caspase inhibitor, z-VAD-FMK $(0,2.5,5$ and $10 \mu \mathrm{M})$ for $48 \mathrm{~h}$. (C) MCF-7 epithelial cells were incubated with $0.2 \mathrm{mg} / \mathrm{mL}$ of TG in the presence of the pan-caspase inhibitor, z-VAD-FMK $(0,2.5,5$ and $10 \mu \mathrm{M})$ for $48 \mathrm{~h}$. The trypan blue exclusion assay was performed to detect the cell viability of cell lines. The cell viability (\%) of cells without TG treatment was set as 100. Data are expressed as the mean \pm SEM from three independent experiments. $P$-values were determined by the Student's $t$-test. $* P<0.05$. 
세포인 U937 단핵구와 Jurkat T 림프구 외에도 비-면역계 세포인 MCF-7 유방암 상피세포에서도 유사한 지방독성 효과가 나타나는 것을 확인할 수 있었다. 또한 중성지방 에 의한 지방독성 효과에 있어 apoptotic caspase 경로가 단핵구나 대식세포에 관여하는 것을 확인한 연구는 있 었으나, T 림프구 및 비-면역계 세포에서 caspase-9 또는 caspase-8이 관여하는 것은 본 연구를 통해 새롭게 밝힐 수 있었다.

중성지방과 지방독성 효과의 연관성은 크게 두 가지 측면에서 다루어지고 있다. 첫 번째는 고지혈증과 관련하 여 세포 밖에서 중성지방에 의한 자극이 있는 경우에 나 타나는 세포 사멸 및 염증 반응 증가와 관련된 연구이다 (Cury-Boaventura et al., 2006; Aronis et al., 2008; Lim et al., 2017). 두 번째는 지방독성을 일으키는 인자 중 하나인 팔 미트산(palmitic acid)과 같은 지방산에 세포가 노출되었을 때 세포 내에서 지방산을 중성지방으로 전환하여 지방독 성으로부터 세포를 보호하는 것과 관련한 부분이다. 이 경 우 지질대사와 밀접한 관련이 있는 peroxisome proliferatoractivated receptor- $\gamma$ (PPAR- $\gamma$ )와 acyl-CoA synthetase (ASCL1) 이 활성화되어 중성지방의 세포 내 합성을 촉진하게 되 고 그 결과, 세포질 내 중성지방 과립(TG droplet)이 증가 하는 것을 볼 수 있다(Listenberger et al., 2003; Bosma et al., 2014). 본 연구 결과에서는 고지혈증에 의한 중성지방의 효과를 관찰하기 위해 세포 밖에 중성지방을 처리하였고 그 결과, 면역계 및 비-면역계 세포에서 모두 apoptotic caspase의 활성화에 의한 지방독성 효과를 관찰할 수 있 었다. 본 연구를 포함한 여러 연구에서 세포질 내 합성 증가에 의해 형성된 중성지방에 의해서는 지방독성 효과 가 잘 나타나지 않으며 세포 밖에서 중성지방에 의한 자 극에 의해 지방독성 효과가 증가하는 것을 보았을 때, 중 성지방이 세포 밖 수용체 또는 세포막에 영향을 주어 나 타나는 것으로 예상된다. 그러나 이것을 확인하기 위해서 는 추가적인 연구가 더 필요하다.

면역계 세포인 단핵구 및 $\mathrm{T}$ 림프구의 지방독성 효과는 고지혈증 환자에서 나타나는 염증성 질환 중 하나인 죽 상동맥경화 발달과 매우 밀접한 관련성이 있다. 죽상동맥 경화 초기 병변 부위에서는 대식세포나 단핵구, $\mathrm{T}$ 림프구 를 포함하는 면역계 세포의 세포사멸 반응이 나타나게 된 다(Kolodgie et al., 2000; Feng et al., 2003). 그리고 이것은 병변 부위의 죽상경화반(atherogenic plaque)을 불안정하게 만들게 되며 여러 자극에 의해 불안정해진 죽상경화반을 둘러쌓고 있는 섬유질 캡(fibrous cap)이 파괴되면 혈액 응
고에 의한 혈전증(thrombosis) 형성에 의해 국소적인 조직 손상만 아니라 심한 경우 심정지에 의한 사망까지 도달할 수 있다(Aronis et al., 2008). 본 연구에서 중성지방에 노출 된 U937 단핵구 세포주 및 Jurkat $\mathrm{T}$ 림프구 세포주의 세 포사멸유도 반응의 증가는 중성지방이 단핵구 및 $\mathrm{T}$ 림프 구를 통해 병변 부위의 발달에 관여할 가능성이 있음을 보여주고 있다.

여러 연구에서 지방독성 반응에 의한 세포사멸유도는 세포 외부의 자극이나 세포 내부에서 유도되는 자극에 의 해 유발될 수 있음을 보여주고 있다. Aronis 등의 연구 결 과에 따르면 중성지방에 노출된 대식세포 또는 $\mathrm{T}$ 림프구 등 면역계 세포 내에서 활성산소종이 증가하게 되고 이로 인해 미토콘드리아의 기능 이상이 나타나는 것을 볼 수 있다(Aronis et al., 2005; Fernanda Cury-Boaventura et al., 2006). 그리고 이러한 미토콘드리아의 기능 이상은 cytochrome $c$ 에 의한 caspase-9의 활성화를 유발하여 intrinsic apoptotic 기전의 활성화를 통한 세포사멸을 유도하게 된 다. 본 연구에서 실제로 중성지방에 노출 시 면역계 세 포인 U937과 Jurkat 세포주에서 모두 caspase-9의 cleaved form의 증가를 확인하였다. 따라서 면역계 세포에서 중성 지방 노출 시 세포사멸의 증가는 미토콘드리아의 기능 이 상과 이로 인한 caspase-9의 활성화가 관여할 가능성이 높 다. 그리고 caspase-9의 활성화로 인해 나타나는 PARP 단 백질의 불활성화는 caspase-3 또는 caspase-7 단백질을 경 유하게 되는데 이전 연구에서 대식세포에서 중성지방에 의한 세포사멸유도 시 caspase-3 및 caspase-7의 활성화가 나타나는 것을 이미 확인한 바 있다(Aronis et al., 2008; Lim et al., 2017). 따라서 단핵구 및 T 림프구 또한 유사 한 경로를 공유할 가능성이 있다. 따라서 이와 관련한 연 구를 더 진행할 필요성이 있다.

외부 자극에 의한 apoptotic caspase 기전의 활성에는 외 부에서 자극을 전달하는 물질과 그 자극을 수용하는 세 포막 내 수용체가 중요하게 관여하게 된다. 그리고 그 자극을 통해 세포 내 신호 전달이 일어나게 되면 주로 caspase-8이 활성화되면서 하위 기전에 존재하는 PARP 단 백질을 불활성화 시켜 세포사멸을 유도하게 된다. 이러한 외부 자극을 전달하는 물질 중 대표적인 단백질이 tumor necrosis factor- $\alpha(\mathrm{TNF}-\alpha)$ 이다. 이전 연구에서 $\mathrm{T}$ 림프구 세 포주인 Jurkat 세포주에 중성지방 처리 시 처리 후 24시간 이내에 TNF- $\alpha$ 의 mRNA 발현량이 2 배 이상 증가하는 것 을 확인하였다. 그리고 $\mathrm{TNF}-\alpha$ 에 대한 수용체인 TNF- $\alpha \mathrm{R}$ 또한 그 발현량이 2 배 이상 증가하였다. 따라서 본 연구 
에서 단핵구 세포주인 U937과 T 림프구 세포주인 Jurkat 세포에서의 caspase- 8 의 활성화에 TNF- $\alpha$ 에 의한 외부 자 극이 관여될 가능성이 있다. 한 가지 특이한 점은 비면역 계 세포인 MCF-7 세포주 또한 caspase-8의 활성이 관찰된 다는 점이다. 그리고 면역계 세포주와는 다르게 caspase-9 의 활성 증가는 나타나지 않았다. 또한 pan-caspase 억제 제 처리 시 세포 생존율이 회복되는 것을 보았을 때 중성 지방에 의한 caspase-8의 활성화가 직접적으로 세포사멸 유도에 관여함을 알 수 있었다. 따라서 다른 비면역계 세 포주를 확보하여 다른 세포주에서도 중성지방에 의한 세 포사멸유도에 caspase-8이 관여하는지 확인할 필요성이 있다.

본 연구에서는 고지혈증을 초래하는 원인 중 하나인 중 성지방에 의한 지방독성 효과가 면역계 세포 및 비면역 계 세포에 어떻게 영향을 미치는지 확인을 하고자 하였 다. 그 결과, 면역계 세포만 아니라 비면역계 세포에 모두 지방독성 효과를 나타내는 것을 확인할 수 있었고 더불 어 세포 수 감소 시 caspase-8 또는 caspase-9을 경유하는 apoptotic caspase 기전이 관여함을 밝힐 수 있었다. 본 연 구를 바탕으로 향후 고지혈증과 관련된 연구에 기초적인 자료를 제공할 뿐 아니라 치료제 개발에 있어 표적 후보 를 제공할 수 있을 것으로 기대한다.

\section{ACKNOWLEDGEMENT}

This work was supported by the National Research Foundation of Korea (NRF) grant funded by the Korea government (MSIT) (NRF-2017R1C1B5076998).

\section{CONFLICT OF INTEREST}

No potential conflict of interest relevant to this article was reported.

\section{REFERENCES}

Aflaki E, Radovic B, Chandak PG, Kolb D, Eisenberg T, Ring J, Fertschai I, Uellen A, Wolinski H, Kohlwein SD, Zechner R, Levak-Frank S, Sattler W, Graier WF, Malli R, Madeo F, Kratky D. Triacylglycerol accumulation activates the mitochondrial apoptosis pathway in macrophages. J Biol Chem. 2011. 286: 7418-7428.

Aronis A, Madar Z, Tirosh O. Mechanism underlying oxidative stress-mediated lipotoxicity: Exposure of j774.2 macrophages to triacylglycerols facilitates mitochondrial reactive oxygen species production and cellular necrosis. Free Radic Biol Med. 2005. 38: 1221-1230.

Aronis A, Madar Z, Tirosh O. Lipotoxic effects of triacylglycerols in j774.2 macrophages. Nutrition. 2008. 24: 167-176.

Bosma M, Dapito DH, Drosatos-Tampakaki Z, Huiping-Son N, Huang LS, Kersten S, Drosatos K, Goldberg IJ. Sequestration of fatty acids in triglycerides prevents endoplasmic reticulum stress in an in vitro model of cardiomyocyte lipotoxicity. Biochim Biophys Acta. 2014. 1841: 1648-1655.

Carmena R, Duriez P, Fruchart JC. Atherogenic lipoprotein particles in atherosclerosis. Circulation. 2004. 109: III2-7.

Cory S, Adams JM. The bcl2 family: Regulators of the cellular life-or-death switch. Nat Rev Cancer. 2002. 2: 647-656.

Cury-Boaventura MF, Gorjao R, de Lima TM, Piva TM, Peres CM, Soriano FG, Curi R. Toxicity of a soybean oil emulsion on human lymphocytes and neutrophils. JPEN J Parenter Enteral Nutr. 2006. 30: 115-123.

de Vries JE, Vork MM, Roemen TH, de Jong YF, Cleutjens JP, van der Vusse GJ, van Bilsen M. Saturated but not monounsaturated fatty acids induce apoptotic cell death in neonatal rat ventricular myocytes. J Lipid Res. 1997. 38: 1384-1394.

Deveraux QL, Reed JC. Iap family proteins--suppressors of apoptosis. Genes Dev. 1999. 13: 239-252.

Elmore S. Apoptosis: A review of programmed cell death. Toxicol Pathol. 2007. 35: 495-516.

Feng B, Zhang D, Kuriakose G, Devlin CM, Kockx M, Tabas I. Niemann-pick c heterozygosity confers resistance to lesional necrosis and macrophage apoptosis in murine atherosclerosis. Proc Natl Acad Sci U S A. 2003. 100: 10423-10428.

Fernanda Cury-Boaventura M, Cristine Kanunfre C, Gorjao R, Martins de Lima T, Curi R. Mechanisms involved in jurkat cell death induced by oleic and linoleic acids. Clin Nutr. 2006. 25: 1004-1014.

Frayn KN. Adipose tissue as a buffer for daily lipid flux. Diabetologia. 2002. 45: 1201-1210.

Hokanson JE, Austin MA. Plasma triglyceride level is a risk factor for cardiovascular disease independent of high-density lipoprotein cholesterol level: A meta-analysis of population-based prospective studies. J Cardiovasc Risk. 1996. 3: 213-219.

Johnson ES, Lindblom KR, Robeson A, Stevens RD, Ilkayeva OR, Newgard CB, Kornbluth S, Andersen JL. Metabolomic profiling reveals a role for caspase-2 in lipoapoptosis. J Biol Chem. 2013. 288: 14463-14475. 
Kamstrup PR. Lipoprotein(a): The common, likely causal, yet elusive risk factor for cardiovascular disease. J Lipid Res. 2017. 58: 1731-1732.

Kischkel FC, Hellbardt S, Behrmann I, Germer M, Pawlita M, Krammer PH, Peter ME. Cytotoxicity-dependent apo-1 (fas/ cd95)-associated proteins form a death-inducing signaling complex (disc) with the receptor. EMBO J. 1995. 14: 5579 -5588 .

Kolodgie FD, Narula J, Burke AP, Haider N, Farb A, Hui-Liang Y, Smialek J, Virmani R. Localization of apoptotic macrophages at the site of plaque rupture in sudden coronary death. Am J Pathol. 2000. 157: 1259-1268.

Kusminski CM, Shetty S, Orci L, Unger RH, Scherer PE. Diabetes and apoptosis: Lipotoxicity. Apoptosis. 2009. 14: 1484-1495.

Lim J, Kim HK, Kim SH, Rhee KJ, Kim YS. Caspase-2 mediates triglyceride ( $\mathrm{tg}$ )-induced macrophage cell death. BMB Rep. 2017. 50: 510-515.

Lim J, Kim SH, Kang YW, Jung BC, Kim HK, Lee J, Lee D, Rhee KJ, Kim YS. Triglyceride up-regulates expression of abcg1 in pma-induced thp-1 macrophages through activation of jnk and p38 mapk pathways. Biomed Sci Lett. 2014. 20: 237-243.

Listenberger LL, Han X, Lewis SE, Cases S, Farese RV, Jr., Ory DS, Schaffer JE. Triglyceride accumulation protects against fatty acid-induced lipotoxicity. Proc Natl Acad Sci U S A. 2003. 100: 3077-3082.
Malhi H, Bronk SF, Werneburg NW, Gores GJ. Free fatty acids induce jnk-dependent hepatocyte lipoapoptosis. J Biol Chem. 2006. 281: 12093-12101.

Malloy MJ, Kane JP. A risk factor for atherosclerosis: Triglyceriderich lipoproteins. Adv Intern Med. 2001. 47: 111-136.

Menet R, Bernard M, ElAli A. Hyperlipidemia in stroke pathobiology and therapy: Insights and perspectives. Front Physiol. 2018. 9: 488.

Norbury CJ, Hickson ID. Cellular responses to DNA damage. Annu Rev Pharmacol Toxicol. 2001. 41: 367-401.

Saelens X, Festjens N, Vande Walle L, van Gurp M, van Loo G, Vandenabeele P. Toxic proteins released from mitochondria in cell death. Oncogene. 2004. 23: 2861-2874.

Son SJ, Rhee KJ, Lim J, Kim TU, Kim TJ, Kim YS. Triglycerideinduced macrophage cell death is triggered by caspase-1. Biol Pharm Bull. 2013. 36: 108-113.

Toth PP. Triglyceride-rich lipoproteins as a causal factor for cardiovascular disease. Vasc Health Risk Manag. 2016. 12: 171-183.

https://doi.org/10.15616/BSL.2019.25.1.66

Cite this article as: Lim J, Yang EJ, Chang JH. Cytotoxic Effect of Triglycerides via Apoptotic Caspase Pathway in Immune and Non-immune Cell Lines. Biomedical Science Letters. 2019. 25: 66-74. 